\title{
Discussion of Phase II Papers
}

SEVERAL DisCusSANTS COMMENTED on the issue of income shares under the Phase II program. R. A. Gordon, William Branson, and others noted that, with productivity growing exceptionally fast because of the rapid cyclical expansion expected in the economy, profit margins would widen so much that some cost absorption by business would still permit the profit share to expand. Arthur Okun noted that Perry's neutrality was defined as the state of income shares that would prevail in the absence of the program and that the cyclical expansion of profit margins that we are experiencing would have occurred anyhow. Gardner Ackley argued that we did not know enough about what has happened to price-cost relations in recent years to take any strong position about what income shares should be. Therefore Perry's neutrality concept should not override the need to slow inflation, and some cost absorption was appropriate as a way to help accomplish this. James Duesenberry and Michael Posner felt that the most serious practical problem was not the question of existing income shares but rather delivering on the promise to slow prices noticeably. The trade unions are reluctant to accept wage controls because they have little faith that the inflation will slow down. Forcing some cost absorption on business will demonstrate that the program's main concern is to slow prices and will in fact slow the inflation more quickly and certainly. George Perry commented that he was not making a case that shares were sacred or that equity demanded neutrality. In practice, he favored a tough application of the Price Commission's basic cost-price rules that would lean much more in the direction of price stability than the commission had until now. In practice, this might well put some downward pressure on profits compared with what they would have been without the program. But he thought the asymmetry in Ackley's cost-absorption rules should be recognized and 
believed that a wage-price program was most likely to command support for an extended period if, in principle, it was neutral about income shares.

Differing views were expressed on the use of profit margin ceilings in Phase II. Alan Greenspan pointed out that the application of the rules on the basis of the margins of individual firms would hold down overall prices and margins more than people thought. The basic problem is that we tend to look at margins on an aggregate or an industry-wide basis, on which they are significantly below base period levels. But the experience of individual firms varies widely within these averages. When any one company within an industry hits the profit rule ceiling, a freeze or rollback of its prices may fix the structure of prices within the entire industry. It could exert significant downward pressure on the average profit margin throughout the industry and force cost absorption by firms well within the profit margin guidelines. Duesenberry thought that using 1968 and 1969 profits as a standard could result in too high a base since these were years of exceptionally low unemployment and high utilization. But Robert J. Gordon pointed out that the rise in profit margins is normally most rapid during the early stages of an expansion. Thus, sharply rising margins, perhaps exceeding 1968-69 levels, experienced as the economy moves toward full employment, need not imply that the profit standards are too liberal.

Okun pointed out that the margin rules would help hold prices down by affecting internal firm decisions without necessarily leading to inefficiency. Within most companies, some executives prefer operating with lower volume and higher profit margins and others with higher volume and lower margins. The profit margin ceiling shifts power within the firm toward the latter group. William Poole, on the other hand, was concerned that the profit rule would lead firms to loosen their cost control. He argued that the profit margin ceiling acts like an excess profits tax for companies that come up against it. He would expect them to react by being more liberal with expense accounts and other nonessential expenditures.

Robert J. Gordon said that he found adjusted hourly earnings for private nonfarm production workers the most reliable index of wage increases. From the table in Fiedler's paper, he noted that this measure had been rising at only a 6.8 percent annual rate in the six months prior to the pricewage freeze. Allowing for a 3.2 percent trend growth rate in productivity, the implied rate of inflation without controls would have been 3.6 percent. The success of the program could be measured by how much below 3.6 percent the rate of inflation falls. However, Okun pointed out that com- 
pensation per manhour, a more comprehensive measure of hourly labor costs, had been rising substantially faster than 6.8 percent; and while both series had defects, the underlying inflation rate may have been faster than 3.6 percent without the program.

Robert J. Gordon disagreed with Houthakker's suggestion that recent growth of the money supply presaged a continuation of inflation. For one thing, he pointed out, sophisticated monetarist models, such as that of the St. Louis Federal Reserve Bank, predicted slower GNP growth than Houthakker had on the basis of recent money growth rates. And further, he argued, money is not related to inflation in the short run according to econometric evidence. The short-run Phillips curve is very flat, so that today even rapid monetary growth should reduce unemployment in the short run with any price effects showing up later, after the economy moves nearer potential.

Greenspan disagreed with Houthakker about how prepared the economy was to operate with a substantial rate of inflation. While he agreed that we could adjust to inflation in many other ways, he saw major problems in adjusting our financial structure. Unlike Brazil, we have a structure with significant differences in the average maturities of assets and liabilities. As a result, he doubted we could operate with a 5 or 8 percent rate of inflation without major changes in our system. 